\title{
МЕТОДИ Й ЗАСОБИ ТЕХНІЧНОЇ ДІАГНОСТИКИ ТЯГОВИХ ДВИГУНІВ ЛОКОМОТИВІВ
}

\author{
Д-р техн. наук В.С. Блиндюк
}

Проведений аналіз існуючих методів та засобів технічної діагностики тягових двигунів локомотивів. Показане, щзо оптимальна система технічної діагностики тягових двигунів повинна раціональним чином сполучати в собі глобальний і локальний контроль їхнього технічного стану.

Ключові слова: рухомий склад, тяговий двигун, технічний стан, методи контролю, схема заміщення.

\section{МЕТОДЫ И СРЕДСТВА ТЕХНИЧЕСКОЙ ДИАГНОСТИКИ ТЯГОВЫХ ДВИГАТЕЛЕЙ ЛОКОМОТИВОВ}

\section{Д-р техн. наук В.С. Блиндюк}

Проведен анализ существующих методов и средств технической диагностики тяговых двигателей локомотивов. Показано, что оптимальная система технической диагностики тяговых двигателей должная рациональным чином совмещзать в себе глобальный и локальный контроль их технического состояния.

Ключевые слова: подвижной состав, тяговый двигатель, техническое состояние, методы контроля, схема замещения.

\section{METHODS AND MEANS OF TECHNICAL DIAGNOSTICS OF TRACTION ENGINES OF LOCOMOTIVES}

\section{Doct. of techn. Sciences V.S. Blinduk}

The analysis of the existing methods and means of technical diagnostics of traction engines of locomotives is carried out. It is shown that the optimum system of technical diagnostics of traction engines due a rational rank to combine in itself global and local control of their technical condition. Thus the statement is provided that by results of expert estimates the most large number of information on technical condition of the electric motor contains in such indicators: for windings of an anchor and excitation - insulation resistance, breakdown strength of windings and their temperature; for a collector node - a dynamic beating of a collector, extent of sparking, total electromotive force of the switched sections; for the brush device - the 
size and speed of wear of brushes; for a bearing block - the vibrospectrogram, temperature of an external ring, chemical composition of lubricant.

Keywords: rolling stock, traction engine, technical condition, control methods, equivalent circuit.

Вступ. В умовах фізичного старіння локомотивного парку, що відбувається на залізничному транспорті України, підвищення надійності експлуатації тягового рухомого складу неможливе без упровадження нових методів контролю якості технічного обслуговування i ремонту тягових електродвигунів (ТЕД). У загальному випадку контроль технічного стану тягового рухомого складу припускає комплексну оцінку апріорно заданого рівня надійності його агрегатів і систем як засобами бортової діагностики в процесі експлуатації, так і на стадії його технічного обслуговування і ремонту. Це викликає необхідність рішення задачі керування технічним станом контрольованих об'єктів.

Аналіз останніх досліджень та публікацій. Оптимальна система технічної діагностики ТЕД повинна раціональним чином сполучати в собі глобальний і локальний контроль технічного стану. Розглянемо останній більш докладно. За результатами експертних оцінок найбільша кількість інформації про технічний стан електродвигуна міститься в таких показниках [1]:

- для обмоток якоря і збудження - опір ізоляції, електрична місткість обмотки і ії температура;

- для колекторного вузла - динамічне биття колектора i його профілограма, ступінь іскріння, сумарна небалансова ЕДС комутованих секцій,;

- для щіткового апарата - величина і швидкість зносу щіток;

- для підшипникового вузла - віброспектрограма, температура зовнішнього кільця, хімічний склад змазки.

Під поняття «опір ізоляції» підпадають два показники: опір міжвиткової ізоляції й опір обмотки щодо корпуса двигуна, причому обоє $є$ дуже важливими. Розглянемо їх по окремості.

Контроль міжвиткової ізоляції роблять на предмет виявлення міжвиткових замикань. На практиці, як правило, зустрічаються такі види замикань [2,3]: замикання усіх витків секції якоря чи частини іiі витків, замикання між двома секціями, які лежать в одному пазу, замикання в лобових частинах обмотки якоря, замикання між будь-якими двома точками обмотки (коли обидві ці точки виявляються гальванічно з'єднаними з яким-небудь провідним елементом конструкції двигуна). В асинхронних двигунах до них додаються замикання між котушками чи котушковими групами однієї фази чи між котушками різних фаз. Діагностичними параметрами, використовуваними при контролі міжвиткової ізоляції, є опір обмоток постійному чи змінному струму, величина напруги, що наводиться в спеціальних електричних котушках, і температура обмоток.

Основна частина дослідження. Найбільш простим i давно використовуваним методом є метод мілівольтметра й амперметра [3], який 
полягає в тому, що до двох суміжних пластин колектора підключають за допомогою щупа джерело постійної напруги і при струмі близько 5...10 А (контроль за показниками амперметра) вимірюють мілівольтметром напруги на цій же парі колекторних пластин (при цьому щітки повинні бути підняті). Секцію, в якій спостерігається міжвиткове замикання, визначають за найменшим показанням мілівольтметра. Цей метод дає достовірні результати тільки у випадку замикання з малим перехідним опором і для обмоток з малою кількістю витків. Остання обставина дозволяє застосовувати його для виявлення замикання в обмотках двигуна постійного струму 3 послідовним збудженням.

Наявність короткозамкнутих витків різко знижує повний опір обмотки змінному струму, тому що індуктивність котушки пропорційна квадрату числа ii витків [4]. Тому певне поширення одержав метод виявлення міжвиткового замикання по величині спадання напруги на випробовуваній обмотці при живленні іï змінним струмом через реостат [3]. Відомий також спосіб виявлення короткозамкнутих витків в обмотках асинхронних електродвигунів на основі безпосереднього вимірювання опорів цих обмоток змінному струмові [5]. Відповідно до цього способу, використовується контроль по розбалансуванню мостової схеми, коли у два плеча вимірювального моста по черзі підключаються по дві фази обмотки, а в два інших плеча - активний опір або місткості однакової величини. Автори роботи [5] рекомендують здійснювати контроль на частоті, на якій добротність фази обмотки двигуна максимальна, i підбором додаткових місткостей створювати на цій частоті резонанс напруг.

Найбільш широкого застосування останнім часом набули імпульсні методи виявлення міжвиткових замикань в обмотках електродвигунів постійного i змінного струму [6,7]: метод «хвилі, що біжить», метод безпосередньої подачі імпульсної напруги на обмотку чи іiі частину, метод індукованої напруги.

Відповідно до методу «хвилі, що біжить» [8], джерело імпульсної напруги з амплітудою 12..15 кВ і частотою близько 50 Гц підключають між одним $з$ виводів обмотки і корпусом двигуна, а вихідний імпульсний сигнал, форма і параметри якого несуть інформацію про стан досліджуваної обмотки, знімають з цієї обмотки контактним чи безконтактним способом, зокрема, за допомогою індукційного датчика. У роботі [6] наводяться докази на користь вибору в якості таких зондувальних коливань імпульсів напруги прямокутної форми, у якості вихідного сигналу розглянута імпульсна напруга, що знімається з другого виводу обмотки. Як адекватна модель тракту поширення зондувальних імпульсів у цій роботі розглянута довга лінія [7], що має схему заміщення елементарної ділянки довжиною $\Delta l$, представлена на рис.1. Перехідний процес, який існує на виході такої довгої лінії, має коливальний характер [15]. Діагностування міжвиткових замикань методом безпосередньої подачі імпульсної напруги на обмотку (зокрема, через колекторні пластини) здійснюється за мінімальним показанням імпульсного вольтметра, підключеного до виходу імпульсного генератора. Цей метод реалізований в 
установках сімейства IB3, різні модифікації яких знайшли застосування на підприємствах залізничного транспорту. Істотними недоліками методу є низька чутливість до міжвиткових замикань 3 досить високим перехідним опором, а також, при діагностуванні обмоток якоря, значне іскріння на контактах вимірювальної установки [9].

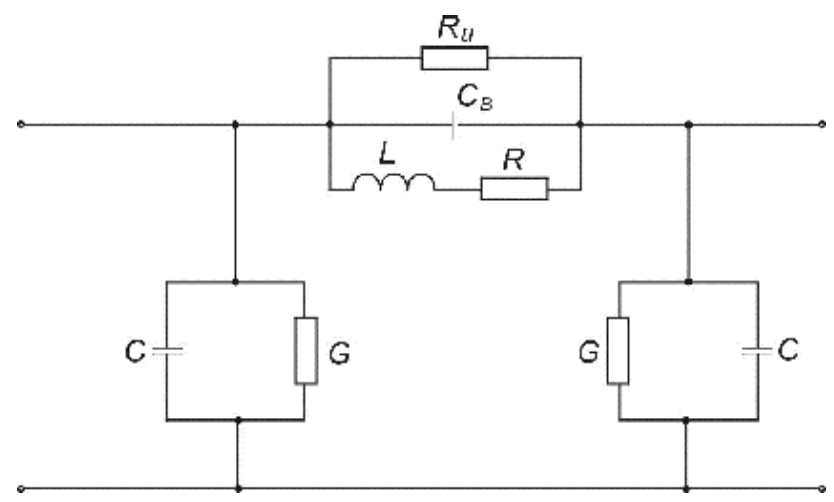

Рис. 1. Схема заміщення елементарної ділянки обмотки електродвигуна:

$R_{n}$ - опір ізоляції елементарної виткової ділянки, обумовлений міжпровідною ізоляцією;

$C_{B}$ - місткість між елементарними витковими ділянками;

$L$ - індуктивність елементарної ділянки проводу;

$R$ - опір елементарної ділянки проводу;

$C$ - місткість елементарної ділянки проводу на корпус;

$G$ - провідність елементарної ділянки проводу на корпус

В основі методу індукованої напруги лежить той факт, що при відключенні якоря від щітково-колекторного вузла в ньому не залишається ніяких гальванічно замкнутих контурів, крім тих, які утворилися через міжвиткові замикання. Якщо тепер подати на обмотку якоря змінну (наприклад, імпульсну) напругу через котушку, індуктивно зв'язану з цією обмоткою, то в короткозамкнутих контурах потече змінний струм, який, у свою чергу, індукує напругу в котушці-датчику. Установка, яка реалізує цей метод, описана в роботі [9]. Певним його недоліком $є$ те, що він дозволяє тільки приблизно визначити місце замикання; для точного визначення місця замикання потрібні додаткові технологічні операції.

Стосовно до обмотки якоря може бути використаний ще один метод виявлення міжвиткових замикань, який не вимагає розбирання двигуна [9]. Відповідно до цього методу колісну пару колісно-моторного блока вивішують і подають на обмотку збудження змінну напругу величиною (10...12) В, потім якір повільно повертає на кут не менше полюсного розподілу двигуна, одночасно знімаючи напругу з щіток протилежної полярності. При відсутності міжвиткового замикання залежність цієї напруги від кута повороту якоря має вигляд пульсацій величиною в соті частки вольта (в ідеально зібраному двигуні вони взагалі повинні дорівнювати нулю). При наявності міжвиткового 
замикання дана залежність має хвилеподібний вигляд 3 розходженням максимуму i мінімуму приблизно в 10 разів i однозначною прив'язкою екстремумів до кутового положення ушкодженої секції обмотки якоря.

Наслідком наявності міжвиткових замикань в обмотках $є$ також нерівномірне нагрівання цих обмоток [10]. Як правило, котушки чи секції, у яких є замикання, перегріті. У асинхронного двигуна з різним ротором коротке замикання в обмотці ротора може також приводити до запуску двигуна при розімкнутому ланцюзі ротора, але це вже явна ознака наявності несправності. Гранично припустимі температури частин (у тому числі й обмоток) електричних машин нормовані відповідно до Держстандарту 183-74 [2]. Відомо, що підвищення температури ізоляції на $10 \%$ понад припустиму величину зменшує іiі термін служби на 50\%, а при iii перегріві на $50^{\circ} \mathrm{C}$ може настати тепловий пробій. Він, зокрема, призведе до збільшення кількості місць замикань в обмотці. Таким чином, для визначення місць існуючих, міжвиткових замикань і місць, у яких міжвиткова ізоляція близька до теплового пробою, можуть бути ефективно використані термодатчики різних типів [12].

Ще одним видом ізоляції, що істотно впливає на працездатність ТЕД, є ізоляція між обмотками двигуна і його корпусом (головна ізоляція машини). Відповідно до Держстандарту 2582-81Е [11] опір ізоляції обмоток нагрітої електричної машини щодо iï корпуса в залежності від номінальної напруги $U$ щодо заземлених частин повинен складати від не менш ніж 1 МОм при $U<400 B$ до більш ніж 5 МОм при $U=(2000 \ldots 3000) B$. Тим часом, тяжкі умови роботи ТЕД (удари і вібрації, змінюване навантаження, різке збільшення частоти обертання при боксуванні, температурні перепади, волога) прямим чи непрямим чином обумовлюють зниження цього опору. Своєчасне виявлення даного зниження і наступне вживання заходів щодо сушіння ізоляції шляхом продування ii вентиляторами чи прогріву струмом дозволить уникнути передчасних необоротних ушкоджень ізоляції. У зв'язку 3 цим безумовно найважливішими $€$ так звані неруйнуючі методи контролю ізоляції: вимірювання активного опору між ізоляцією i корпусом, пї електричної місткості при різних температурах і на різних частотах, вимірювання тангенса кута діелектричних втрат, вимірювання струму абсорбції, вимірювання інтенсивності часткових розрядів в ізоляції.

Найбільш простим способом $є$ вимірювання активного опору між корпусом і виводом обмотки за допомогою мегомметра [3]. Однак, цей спосіб дозволяє виявити лише грубі дефекти. Крім того, у роботі [9] констатовано, що через зволоження ізоляції в процесі експлуатації величина зазначеного опору часто виявляється нижче $(0,5 \ldots 1)$ Мом; при цьому показання мегомметра близькі до нуля, що може бути помилково інтерпретовано обслуговуючим персоналом як наявність необоротного дефекту ізоляції, у результаті чого, замість сушіння ізоляції, може бути зроблена дорога заміна ТЕД.

Більш широке застосування знайшов метод контролю стану ізоляції за швидкістю спаду струму абсорбції, тобто струму, викликаного поглинанням заряду усередині ізоляції при їі живленні від джерела постійної напруги. Даний 
метод базується на резистивно-ємкісній моделі багатошарової ізоляції. Наприклад, для двошарової ізоляції жї еквівалентна схема згідно 3 [9] має вигляд, поданий на рис. 2.

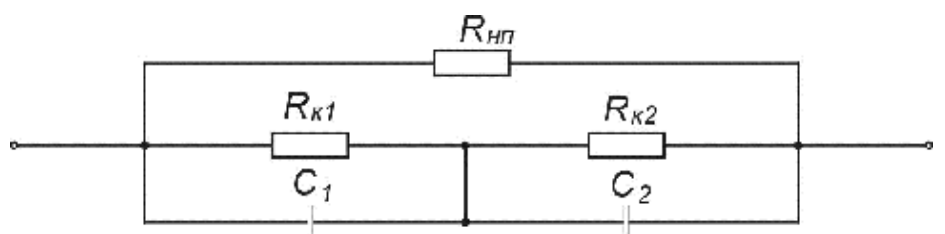

Рис. 2. Еквівалентна схема двошарової ізоляції

$R_{k 1}, R_{k 2}$ - опори шарів ізоляції, обумовлені наявністю вологи, що заповнює капіляри;

$R_{\text {ни }}$ - опір зовнішньої поверхні ізоляції, обумовлений іiі зволоженням i забрудненням;

$C_{1}, C_{2}$ - місткості шарів ізоляції

Швидкість спаду струму абсорбції характеризують побічно, використовуючи коефіцієнт абсорбції [9]

$$
K a=\frac{R_{60}}{R_{15}},
$$

де $R_{15} \mathrm{i} \quad R_{60}$ - опори ізоляції, зафіксовані відповідно через $15 \mathrm{c}$ і через $60 \mathrm{c}$ після початку вимірювання.

У роботі [9] описано пристрій, що дозволяє здійснювати безупинний контроль стану ізоляції ТЕД електровозів змінного струму шляхом вимірювання величини струму витоку в ланцюзі реле заземлення. При прийомі електровоза на лінії чи при виїзді з депо машиніст, використовуючи даний пристрій, встановлений усередині високовольтної камери електровоза, може швидко виявити двигун, у якому неприпустимо зменшився опір головної ізоляції, і вжити заходів до іï сушіння.

Ще одним характерним ушкодженням ТЕД $є$ обриви електричних ланцюгів обмоток, що виникають, як правило, через неякісно виконане закладення кінців обмоток у патрони, ушкодження ізоляції при укладанні обмоток, ослаблення кріплення котушок на сердечниках та ін. Якщо місця обриву не видно при зовнішньому огляді, то сам факт наявності обриву чи поганого контакту в обмотці двигуна постійного струму позначається на його комутації, викликаючи в підсумку значне іскріння на колекторі і підгоряння колекторних пластин; у той же час для асинхронного електродвигуна подібні помітні вторинні ознаки обриву відсутні [3]. Для виявлення місць обривів може бути використаний вже описаний вище метод мілівольтметра й амперметра (для ТЕД постійного струму). Для виявлення обривів в обмотках статора асинхронних ТЕД з успіхом може бути застосоване вимірювання опору між нейтраллю і кінцями фаз обмоток (при з'єднанні обмоток зіркою $з$ доступною 
нейтраллю), або між кінцями фаз (при з'єднанні обмоток зіркою з недоступною нейтраллю чи при з'єднанні обмоток трикутником) [3]. Той же автор рекомендує для виявлення обриву чи поганого контакту в короткозамкнутих обмотках ротора вимірювати силу струму в одній чи декількох фазах статора при подачі на статор напруги, рівної (20...25)\% номінальній, і примусовому повільному обертанні ротора. При відсутності дефектів ця сила струму не залежить від положення ротора, при їхній наявності помітно змінюється 3 поворотом останнього.

Відомий також спосіб виявлення обривів за аномальною конфігурацією зовнішнього магнітного поля двигуна, заснований на обходженні струмом місць обриву, але він має дуже низьку завадостійкість стосовно сторонніх магнітних полів [9].

Слабким місцем обмоток ТЕД постійного струму $€$ міжкотушкові з'єднання і місця закладення виводів котушок; на їх частку припадає близько $14 \%$ відмовлень ТЕД. Порушення цих з'єднань супроводжуються істотним місцевим нагріванням, тому для їхньої діагностики з успіхом можуть бути застосовані термодатчики різного типу, контактні і безконтактні [9]. До числа контактних термодатчиків відносяться термоіндикатори плавлення, які необхідно змінюють свій колір при досягненні елементом конструкції, на якому вони закріплені, певної температури, що залежить від моделі термоіндикатора.

Такі датчики можуть бути встановлені у важкодоступних місцях, у них високий електричний опір, на них практично не впливає зовнішнє електромагнітне поле з частотами від дуже низьких до надвисоких. Їхній недолік - однократність дії.

Контактними термодатчиками є також термометри і термопари. Перші підрозділяють на термометри розширення i тиску; у них використана властивість рідин змінювати свій об'єм у залежності від температури. Існують також електричні термометри опору, засновані на принципі зміни активного опору провідників і напівпровідників у залежності від температури. Нарешті, застосовують i конденсаторні термодатчики (в електричних машинах переважно на базі сегнетоелектриків, нечутливих до зовнішнього магнітного поля), у яких місткість виміряється в залежності від температури. Контактні термодатчики на базі термопар засновані на температурній залежності ЕДС, яка виникає в місці спаювання двох різних металів. Усі типи датчиків, за винятком термометрів розширення i тиску, добре пристосовані для дистанційного контролю температури у важкодоступних місцях електричних машин; відповідна методологія докладно розглянута в роботі [12].

Відповідно до роботи [9], одержав поширення і безконтактний метод вимірювання температури міжкотушкових з'єднань за інтенсивністю інфрачервоного випромінювання від них. Як діагностичний параметр рекомендують використовувати температуру зовнішньої поверхні ізоляції, що залежить від наявності і ступеня порушення контакту i, у той же час, найменш залежну від впливу сторонніх факторів. Для дистанційного вимірювання температури використовують зовнішні прилади - інфрачервоні болометричні радіометри, інфрачервоні термометри - дефектоскопи і пірометри, при цьому 
для контролю таких компактних об'єктів, як місця пайок і болтові з'єднання, кращим $є$ застосування тих моделей перерахованих приладів, що мають високу просторову вибірковість. Певну інформацію про відмовлення чи передвідмовний стан електродвигуна несе i просторово не локалізована температура його окремих вузлів і всього двигуна в цілому [10-14]. Перегрів двигуна відбувається при його механічному перевантаженні чи перевантаженні струмом при номінальній потужності (останній спостерігається в асинхронних двигунів при зниженій напрузі живлення), а також при незадовільній роботі системи охолодження [3]. Для інтегрального контролю температури двигуна чи його великих вузлів застосовують як прямі, так i непрямі методи іï вимірювання.

Висновок. Ефективність роботи залізничного транспорту в значній мірі залежить від технічного стану локомотивного парку. Для забезпечення необхідних обсягів і термінів перевезень, безпеки руху поїздів необхідно так будувати стратегію технічного обслуговування локомотивів, щоб постійно підтримувати їхню надійність на необхідному рівні. Впровадження в практику нових методів і засобів діагностування та прогнозування технічного стану тягових двигунів $\epsilon$ важливою науково-технічної задачею удосконалення ефективності контролю технічного стану локомотивів.

\section{Список літератури}

1. Котеленец Н.Ф., Кузнецов Н.Л. Испытания и надежность электрических машин. - М.: Высш. школа, 1988. - 232 с.

2. ГОСТ 183-74 Машины электрические вращающиеся. Общие технические требования.

3. Гемке Р.Г. Неисправности электрических машин. - Л.: Энергоатомиздат, Ленинградское отделение, 1989. - 334c.

4. Калантаров П.Л., Цейтлин Л.А. Расчет индуктивностей. Справочная книга. - Л.: Энергоиздат, Ленинградское отделение. 1986. - 488c.

5. Схемы обнаружения короткозамкнутых витков в обмотках асинхронных двигателей с тремя выводными концами / Ю.К. Горбунов, В.И. Гуков, В.Г. Тихобаев и др.// Электротехника. - 1989. - №3. - С.24-28.

6. Хомутов О.И.. Система технических средств и мероприятий по повышению надежности электрооборудования. - Барнаул: Алтайский политехн. ин-т им. И.И. Ползунова, 1989. - 96 с.

7. Бессуднов Е.П. Обнаружение мест дефектов изоляции обмоток электрических машин постоянного тока. - М. - Энергия, 1977. - 120c.

8. Електротехніка та електромеханіка систем залізничної автоматики [Текст]: підручник / М.М. Бабаєв, М.Г.Давиденко, Г.І. Загарій, Ю.В. Соболєв, В.С. Блиндюк, О.М. Прогонний, О.М. Ананьєва, К.А. Трубчанінова: підручник. - Харків: УкрДАЗТ, 2011.- 608 с.

9. Волков В.К., Суворов А.Г. Повышение эксплуатационной надежности тяговых двигателей. - М.: Транспорт, 1988. - 128c. 
10. Блиндюк, В.С. Моделирование теплового режима работы тягового двигателя в задаче автоматического управления моторвагонным подвижным составом [Текст] / В.С. Блиндюк // Зб. наук. праць. - Донецьк: ДонІЗТ, 2012. Вип. 29. - С. 242-246.

11. ГОСТ 2582-81Е. Машины электрические вращающиеся тяговые. Общие технические требования.

12. Богаенко И.Н. Контроль температуры электрических машин. - К.: Техника, 1975. - 176c.

13. Чепцов, М.М. Нейромережева модель динамічного логічного елементу “НІ" [Текст] / М.М. Чепцов, М.М. Бабаєв, В.С. Блиндюк // Зб. наук. праць. - Харків: УкрДАЗТ, 2012. - Вип. 128. - С. 165-175.

14. Блиндюк, В.С. Прогнозне нейромережеве моделювання теплових режимів функціонування тягових двигунів моторвагонних рухомих одиниць [Текст] / В.С. Блиндюк // Інформаційно-керуючі системи на залізничному транспорті. - 2012. - № 2. - С. 87-96.

15. Соболєв Ю.В. Теорія електричних і магнітних кіл [Текст] / Ю.В.Соболєв, М.М.Бабаєв, М.Г.Давиденко, - Харків: ХФВ «Транспорт України». - 2002. 264c.

Блиндюк Василь Степанович, д-р техн. наук, професор кафедри електротехніки та електричних машин Українського державного університету залізничного транспрту, Харків, Україна. Тел.: (057) 730-10-03. Vasiliy Blinduk., Doktor of Engineering, professor department of electrical engineering and electrical machines Ukrainian State University of Railway Transport, Kharkiv, Ukraine. Tel.: (057) 730-10-03.

Наукова праця здана до друку 08.09.2015 року 